Article

\title{
Does an Emissions Trading Policy Improve Environmental Efficiency? Evidence from China
}

\author{
Yifei Zhang ${ }^{1}$, Sheng $\mathrm{Li}^{2}{ }^{2 *}$ and Fang Zhang ${ }^{3}$ \\ 1 School of Economics, Zhejiang University of Technology, Hangzhou 310014, China; yifeizhang@zjut.edu.cn \\ 2 Gulf Coast Research and Education Center, University of Florida, Wimauma, FL 33598, USA \\ 3 Belfer Center for Science and International Affairs, Harvard Kennedy School, Cambridge, MA 02138, USA; \\ fangzhang@hks.harvard.edu \\ * Correspondence: lisheng@ufl.edu
}

Received: 6 January 2020; Accepted: 6 March 2020; Published: 11 March 2020

check for updates

\begin{abstract}
An emissions trading system is a market instrument for pollution control that has been used in China for many years. The Ministry of Environmental Protection of China has approved the implementation of emissions trading pilot projects in 11 provinces since 2007, yet the effectiveness of the policy has not been comprehensively estimated. With panel data from 29 provinces and cities in China between 2003 and 2012, this study uses the data envelopment model-slack based measurement (DEA-SBM) method to measure environmental efficiency indicators and a difference in difference (DID) model to examine the impact of the emissions trading system on environmental efficiency. The results indicate that the policy has significantly improved environmental efficiency in the pilot provinces. However, the effects are heterogeneous with different efficiency levels across the diverse regions. Higher impacts were found in the central and western regions. Some suggestions for the optimization of the emissions trading system are suggested in this study.
\end{abstract}

Keywords: emission rights trading system; environmental efficiency; DEA-SBM method; DID; China

\section{Introduction}

The Chinese economy has developed rapidly in recent decades as a result of economic reforms. However, alongside this economic development, environmental issues have become increasingly prominent $[1,2]$. The recent outbreak of a series of environmental pollution incidents, such as the cyanobacteria in Tai Lake during the summer of 2007, the national smog in the winter of 2012, and the dead pigs floating in the Huangpu River in 2013, highlight the negative environmental externalities that accompany Chinese economic growth [3-5]. These problems seriously affect individuals' health and regional environmental sustainability [6,7].

In order to alleviate the problems associated with the use of environmental resources and economic development, governments have developed a series of environmental instruments since the 1980s. One of the most important policies is the emissions trading policy. In 1989, the National Environmental Protection Administration issued "Measures for the Implementation of Water pollution permit", which is the first law regarding water pollution permit. Since then, the central government started to introduce the pollution trade system in some pilot cities. The emission trading system was initiated in the 2000s, and it aimed to control the acid rain issues in some cities. In 2001, the first transaction for Sulfur dioxide was closed in Jiangsu province. The following regions including Shandong province, Shanxi province, Shanghai, etc. joined the trade market. The water emission trading system started to establish in 2001. Since piloting the emissions trading policy in 2002, 11 provinces, including Hebei, Henan, Hubei, Hunan, Jiangsu, Inner Mongolia, Shanxi, Shaanxi, Tianjin, Zhejiang, and Chongqing, have participated, and environmental quality has been significantly improved in recent years. The 
State Council promulgated the pilot project and further promoted the paid use and trading of emission rights in the market in 2007. The purpose is to further utilize and improve the emissions trading market and achieve energy conservation and emission reduction targets.

The proper use of environmental resources can promote the sustainable development of the social economy $[8,9]$. The emissions trading policy emphasizes market mechanisms to adjust emissions, encouraging enterprises to improve their own emission reduction technologies and thereby achieve environmental governance goals [10-12]. Compared with other environmental tools, the emission trading policy can effectively reduce management costs for enterprises through information disclosure and trading platforms and prevent the occurrence of "government failure" [13,14]. The control system and the paid use of environmental resources help to improve the quality of the ecological environment and transform the model of economic development to one which is more environmentally sustainable. Thus, it is important to examine the implementation of emissions trading systems and to calculate the environmental dividends for enterprises and society.

An emissions trading system helps to alleviate the environmental resources shortage crisis [15]. Many studies have evaluated the effectiveness of this environmental tool in China, but most have focused on analyzing the short-term emission reduction effects. For example, Li and Shen (2008) [16] use industrial provincial panel data (1996-2005) to find that the collection system of sewage charges has a more significant impact on emission reductions compared to the emission trading system. Jin and Shen (2010) [17] suggest that the emissions trading system has improved social welfare and solved the environmental externalities. Yan and Guo (2012) [18] use the difference in difference (DID) model to show that the amount of sulfur dioxide produced has reduced significantly due to the implementation of the trading policy.

In addition to emissions reduction, the environmental tools of emission rights may also generate benefits for environmental governance and economic performance [19,20]. Brannlund et al. (1998) [21] use the data envelopment analysis (DEA) efficiency model and find that the Swedish paper industry achieved maximum yields under the system of emissions trading. Fare and Ahmed (2014) [22] extend Brannlund's model and suggest the emissions trading system can bring significant economic dividends to enterprises. Chen (2010) [23] simulates the gains and losses to China in the next 50 years and find that although the technological progress of energy-saving and emission reduction has a negative impact in the short-term, the growth rate of all factors will maintain a stable trend in a long run and achieve a win-win situation for the economy and the environment.

Existing research mainly focuses on system design, system improvement, and legal norms [24-26]. Policy evaluations are mostly concentrated on the reduction of sulfur dioxide emissions, while studies on water pollution rights transactions are rare $[27,28]$. Some research has examined the environmental and economic effects following the introduction of emissions trading [29,30]. However, studies about environmental governance efficiency and environmental economic efficiency are limited [31,32]. Most of the literature on environmental governance efficiency focuses on energy use and emission reduction policies [33-35], which has limited application to emissions trading systems. This paper assesses the evolution of China's emissions trading system in the pilot areas and applies a DEA-slack based measurement (SBM) method to measure regional efficiency indicators including environmental governance efficiency and environmental economic efficiency. Finally, based on the panel data of 29 provinces and cities between 2003 and 2012, a DID method is used to evaluate the implementation effects of the emission trading system. The existing problems and countermeasures to them are also proposed and discussed.

\section{Methodology and Data}

\subsection{Environmental Efficiency Evaluation}

Following previous studies, we use the DEA method to evaluate environmental efficiency across the study area. DEA has been widely used for evaluating environmental governance and technical 
efficiency in recent years $[31,36,37]$. The main principle of this method is to measure the changes in productivity or economic output under the constraints of environmental resources through an increase or decrease in inputs and outputs of different proportions and along different vectors [38]. However, this method can be biased if investment and production are insufficient or if production is too high [39,40]. Tone (2001) proposes a non-radial, non-angled DEA, slack based measurement (SBM), which improves the conditions of input and output slack variables [41]. In this study, we employed a DEA-SBM method to measure environmental governance efficiency and environmental economic efficiency.

\subsubsection{Environmental Governance Efficiency}

Assuming each decision-making unit (a province in this study) uses $n$ inputs with an input matrix of $X=\left(x_{1}, x_{2} \ldots x_{n}\right) \in R_{+}^{n}$ to produce $m$ outputs with an output matric $Y=\left(y_{1}, y_{2} \ldots y_{m}\right), \in R_{+}^{m} ; \lambda$ is the weight of the coefficient vector, $\lambda \geq 0 ; \mu^{+}$represents the output relaxation vector, $\mu^{+} \geq 0 ; \mu^{-}$ represents the input relaxation vector, and $\mu^{-} \leq 0$. Then, the environmental efficiency measurement model of the province to be assessed is:

$$
\min _{\theta \in\{1, \ldots, n\}} E_{\theta}=\frac{1-\frac{1}{n} \sum_{i=1}^{n} \frac{\mu_{i}^{-}}{x_{i 0}}}{1+\frac{1}{m} \sum_{i=1}^{m} \frac{\mu_{r}^{+}}{y_{i 0}}}
$$

subject to:

$$
\begin{gathered}
\sum_{i=1}^{n} x_{j i} \lambda_{i}+\mu_{j}^{-}=x_{i 0}, j=1, \ldots n \\
\sum_{i=1}^{n} y_{j i} \lambda_{i}-\mu_{k}^{+}=y_{k 0}, j=1, \ldots m \\
\lambda \geq 0, \mu_{i}^{-} \geq 0, \mu_{i}^{+} \geq 0
\end{gathered}
$$

where $E_{\theta}$ represents the $\theta$-th environmental management efficiency of the resource (the water or atmosphere), $x_{0}$ is the input vector, $y_{0}$ is the output vector, $\mu_{r}^{+}$is the $r$-th output indicator, and $\mu_{i}^{-}$ is the $i$-th input indicator. When $E_{\theta}=1$ then environmental governance is perfectly effective with $\mu_{r}^{+}=\mu_{i}^{-}=0$, implying there is no redundant input or output. When $0 \leq E_{\theta}<1$, environmental governance in the region is not effective, and there is potential for improving it.

\subsubsection{Environmental Economic Efficiency}

Based on the assumptions of Model 1, the input factors are unchanged, and $m_{1}$ represents the number of environmental positive goods with a vector of $Y_{m_{1}}^{g}=\left(y_{1}^{g}, y_{2}^{g} \ldots y_{m_{1}}^{g}\right) \in R_{+}^{m_{1}} ; m_{2}$ represents the number of environmental negative goods with a vector $Y_{m_{2}}^{b}=\left(y_{1}^{b}, y_{2}^{b} \ldots y_{m_{2}}^{b}\right) \in R_{+}^{m_{2}}$, the production possibility sets are

$$
P(x)=\{(y, b): x \text { produce }(y, b)\}, x \in R_{+}^{m_{1}}
$$

The environmental economic efficiency measurement model to be evaluated is:

$$
\min _{\theta \in\{1, \ldots, n\}} E E_{\theta}=\frac{1-\frac{1}{n} \sum_{i=1}^{n} \frac{\mu_{i}^{-}}{x_{i 0}}}{1+\frac{1}{m_{1}+m_{2}}\left(\sum_{r=1}^{m_{1}} \frac{\mu_{r}^{g}}{y_{r 0}^{g}}+\sum_{r=1}^{m_{2}} \frac{\mu_{r}^{b}}{y_{r 0}^{b}}\right)}
$$

subject to:

$$
\begin{aligned}
& \sum_{i=1}^{n} x_{j i} \lambda_{i}+\mu_{j}^{-}=x_{i 0}, j=1, \ldots m \\
& \sum_{i=1}^{n} y_{j i}{ }^{g} \lambda_{i}-\mu_{k}^{g}=y_{k 0}, j=1, \ldots m_{1}
\end{aligned}
$$




$$
\begin{gathered}
\sum_{i=1}^{n} y_{j i}^{b} \lambda_{i}-\mu_{k}^{b}=y_{k 0}, j=1, \ldots m_{2} \\
\lambda \geq 0, \mu_{i}^{-} \geq 0, \mu_{i}{ }^{+} \geq 0
\end{gathered}
$$

where $E E_{\theta}$ represents the $\theta$-th environmental economic efficiency. $\mu_{r}^{g}$ is product shortage for the environmental positive goods, and $\mu_{r}^{b}$ is product shortage for the environmental negative goods. When $E E_{\theta}=1$, then the environmental economy of the unit is perfect effective with $\mu_{r}^{g}=\mu_{r}^{b}=\mu_{i}^{-}=0$, and when $0 \leq E E_{\theta}<1$, this implies that the regional environmental economy still has potential dividends that can be released.

\subsection{Emissions Trading System Effect Estimation: A DID Model}

The effects of the emissions trading system on environmental efficiencies can be estimated by the DID model. The DID model is a widely used method for policy evaluation that essentially estimates the net impacts of a policy on the people it acts on [42-44]. The model divides the sample into a control group and a treatment group. The control group is the object that has not been affected by the policy, the treatment group is the object affected by the policy, and then the policy is implemented by changing the two groups of experiments accordingly. In recent years, many studies have used this method to evaluate the emission reduction effect of the emissions trading policy [45-47]. In this study, we use 11 provinces and municipalities (Hebei, Henan, Hubei, Hunan, Jiangsu, Zhejiang, Tianjin, Chongqing, Inner Mongolia, Shanxi, and Shaanxi) that piloted emissions trading in 2007 as treatment groups, and then employe propensity score matching (PSM) to match the remaining 18 provinces as control groups. The PSM method is used to find the control group with respect to the time of policy implementation, divide into the non-pilot period (2003-2006) and the pilot period (2007-2012). We set the period before the pilot of emissions trading policy to be 0 , and the period after the implementation of the emissions trading policy to be 1 . The provinces in effect are indicated by the dummy variable treated, treated $=0$ represents the unpiloted area, treated $=1$ represents the pilot area, and the interaction between the period and the treated area is the net effect of the policy. The baseline model can be summarized as:

$$
Y_{i}=\beta_{0}+\beta_{1} \text { period }+\beta_{2} \text { treated }+\beta_{3} \text { period } \times \text { treated }+\varepsilon
$$

where $Y_{i}$ is the environmental governance efficiency or environmental governance performance in the province, and the interaction term $\beta_{3}$ is the effect of the policy.

In order to better estimate the model and reduce bias, we expand the basic model by incorporating a control variable matrix based on previous studies [48-50]. This included eight factors: the capital investment in enterprise environmental governance, the collection of sewage charges, the level of economic development, the living standards level of each region, the degree of industrialization in each region, the ownership structure, the proportion of heavy industry, and whether the province is in the central and western regions. Equation (3) can be seen as:

$$
\begin{aligned}
E=\beta_{0}+\beta_{1} \text { period } & +\beta_{2} \text { treated }+\beta_{3} \text { period } \times \text { treated }+\alpha_{1} \ln \text { eaw }+\alpha_{2} \ln \text { plf } \\
& +\alpha_{3} \ln g d p p+\alpha_{4} \ln \text { urb }+\alpha_{5} \text { ind } d_{\text {rate }}+\alpha_{6} \text { storate }+\alpha_{7} \text { hi } i_{\text {rate }} \\
& +\alpha_{8} \text { exeast }+\varepsilon
\end{aligned}
$$

where $E$ represents indicators such as wastewater environmental treatment efficiency $(E W)$, waste gas environmental treatment efficiency (EG), wastewater environmental economic efficiency (EEW), and gas environmental treatment efficiency (EEG).

eaw represents self-raised funds by enterprises to measure their environmental awareness. The environmental awareness of enterprises has a significant impact on regional environmental governance efficiency [51,52]. Companies' stronger awareness of environmental governance is associated with a higher level of environmental technologies, more enterprises participating in the environmental guidelines advocated by the government, and improved environmental management efficiency. 
$p l f$ is the degree of regional environmental supervision. The sewage charge system is the main system for the implementation of pollution control in China and represents the intensity of environmental regulation. It has been shown that the sewage charge system has improved environmental quality and achieved the goal of emissions reduction in recent years [53,54]. However, the effects are heterogeneous across regions. Areas with higher charging standards have a greater degree of environmental supervision, and vice versa. We use charging standards as a proxy variable for regional environmental supervision.

$g d p p$ represents per capita gross domestic product (GDP) and is used to measure the economic development and living standards of residents in each region. Generally speaking, the higher the living standards of residents in a region, the higher the demand for good environmental quality. This leads to the government increasing investment in the monitoring of the environment, thereby affecting regional environmental governance and affecting the level of environmental economic efficiency [55-57].

$u r b$ is the urbanization rate calculated by the urban population/total population. Most scholars believe that the process of urbanization has an impact on environmental pollution [58,59]. The main reason is that the acceleration of urbanization brings increasing amounts of polluting emissions and reduces the efficiency of environmental pollution treatment. However, the expansion of urbanization also brings a shift in heavy industry to the tertiary industry, thereby improving environmental and economic efficiency and increasing the degree of emissions trading $[60,61]$.

$i n d_{\text {rate }}$ is the ratio of the output value of industrial enterprises above a designated size (in terms of the value of output) to the GDP to measure the intensity of industrialization. Most studies have shown that the higher the intensity of industrialization, the more serious the pollution situation, and the relatively lower level of environmental governance and economic performance, which affects the implementation of emissions trading policies $[62,63]$.

$s t o_{\text {rate }}$ is the proportion of industrial output value of the state-owned and state-holding enterprises above a designated size over the total industrial output value, which measures the strength of ownership. State-owned and state-held enterprises more strongly emphasize economic outputs and benefits but might ignore the negative effects of environmental pollution on society. In general, the higher the proportion of enterprises, the more serious their pollution will be [64,65]. However, large state-owned and state-holding companies often have a brand associated with greater social responsibility, and as such are required to demonstrate more investment in pollution control. Thus, the ownership structure may have dual impacts on regional pollutant emissions.

$h i_{\text {rate }}$ represents the proportion of the output value of heavy industrial enterprises to the total output value of industrial enterprises to measure the industrial structure. Heavy industrial enterprises are the main source of pollution emissions. With the rapid economic reforms, heavy industrial enterprises have shifted from first-tier cities to inland cities, while less-developed areas have gradually become "pollution havens". This may have a certain degree of negative impact on regional environmental governance efficiency and economic performance. The implementation of emissions trading policies also increases the cost of heavy industrial enterprises' pollution control, which affects the regional industrial structure.

exeast is a regional dummy variable for the eastern region with 0 and 1 for otherwise. The level of economic development in the east of China is much higher than in other regions which might lead to heterogeneity issues in the estimation. The dummy variable can be used to control the possible heterogeneity with other regions.

\subsection{Data}

The sample interval studied in this paper is from 29 provinces in China from 2003 to 2012. Due to the lack of data, Tibet, Qinghai, Hong Kong, Macao, and Taiwan regions were not included in the scope of this study. The variable data mainly comes from the 2004-2013 China Environmental Statistics Yearbook, the 2004-2013 China Statistical Yearbook, the 2005-2013 China Environmental Yearbook, 
and the 2004-2013 China Industrial Economics Statistical Yearbook. The descriptive statistical analysis of the variables is shown in Table 1.

Table 1. Descriptive statistical analysis of variables.

\begin{tabular}{|c|c|c|c|c|c|}
\hline Variable & Description & Mean & $\begin{array}{l}\text { Standard } \\
\text { Deviation }\end{array}$ & Min & Max. \\
\hline eaw & $\begin{array}{l}\text { Self-raised funds by enterprises (10 thousand } \\
\text { Yuan) }\end{array}$ & 11.61 & 0.86 & 8.39 & 14.19 \\
\hline plf & $\begin{array}{c}\text { Degree of regional environmental supervision } \\
\text { (sewage charges) }\end{array}$ & 10.55 & 0.86 & 7.65 & 13.03 \\
\hline ind & $\begin{array}{l}\text { The ratio of the output value of industrial } \\
\text { enterprises above designated size to the GDP }\end{array}$ & 0.43 & 0.07 & 0.19 & 0.57 \\
\hline sto & $\begin{array}{c}\text { The proportion of industrial output value of } \\
\text { the state-owned and state-holding enterprises } \\
\text { above designated size over the total industrial } \\
\text { output value }\end{array}$ & 0.47 & 0.22 & 0.11 & 0.82 \\
\hline$h i$ & $\begin{array}{l}\text { The proportion of the output value of heavy } \\
\text { industrial enterprises to the total output value } \\
\text { of industrial enterprises }\end{array}$ & 0.75 & 0.12 & 0.44 & 0.95 \\
\hline$g d p p$ & Per capita GDP (10 thousand Yuan) & 9.88 & 0.68 & 8.19 & 11.35 \\
\hline$u r b$ & $\begin{array}{l}\text { The urbanization rate(urban population/total } \\
\text { population) }\end{array}$ & 0.46 & 0.16 & 0.86 & 0.23 \\
\hline exeast & $\begin{array}{l}\text { Tegional dummy variable for eastern region } \\
\text { with } 0 \text { and } 1 \text { for otherwise }\end{array}$ & 0.65 & 0.48 & 0 & 1 \\
\hline
\end{tabular}

To study environmental governance efficiency, the selected input indicators were the funds and equipment invested in environmental governance. The output indicators were emissions data such as the emissions standards along two dimensions: wastewater treatment and air pollution treatment. The specific explanations are as follows.

a. Direct capital investment in environmental treatments, including the amount of investment in wastewater treatment and the amount of investment in air pollution treatment.

b. Labor input. We selected the number of full-time employers that engage in environmental protection activities to measure a region's human resources in environmental governance.

c. Technical inputs, including the number of operating systems for wastewater and air pollution.

d. Treated outputs, referring to the amount of wastewater and air pollution discharged up to the standard, and the amount of industrial wastewater and industrial air pollution discharged.

Similarly, environmental economic efficiency was measured in terms of maximizing environmental resource utilization. In this study, we define the total industrial output value of industrial enterprises above the designated size (annual income over 20 million RMB) in each region as the "good" product, and the associated total demand for the chemical oxygen and the total emissions of sulfur dioxide as the "bad" product. The environmental economic efficiency of water and atmosphere include:

a. Capital investment, the net value of industrial fixed assets above the designated size.

b. Labor input, the number of employers in industrial enterprises above the designated size.

c. Resources and energy inputs. The use of environmental and energy resources are important to input through the production process of enterprises, and they are also the main source of pollutant emissions.

Before modeling, we apply the unit root test (Im-Pesaran-Shin test) to test the possible autocorrelations for all variables. Following IM et al. (2003) and Pesaran (2015), The cross-sectional averages are subtracted from the series to mitigate the impact of cross-sectional dependence. The number of lags of the series is chosen such that the AIC for the regression is minimized $[66,67]$. The advantage of the Im-Pesaran-Shin test is to relax the assumption of a common $\rho$ and instead allow each panel to have its own $\rho_{i}$ [66]. The results in Table A1 (Appendix A) showed that all variables reject the null hypothesis that contains unit-roots. 


\section{Results}

\subsection{Comparative Analysis of Regional Environmental Treatment Efficiency}

Using provincial panel data from 2003 to 2012, we apply DEA-solver software to calculate the environmental treatment efficiency for wastewater (EW), environmental treatment efficiency for gas pollution (EG), and treatment environmental economic efficiency for wastewater (EEW) and gas pollution (EEG) at the provincial level. We compare those indicators before and after the pilot implementation (2007) as shown in Table 2.

Table 2. Comparison of the regional environmental and economic treatment efficiency before and after the pilot implementation.

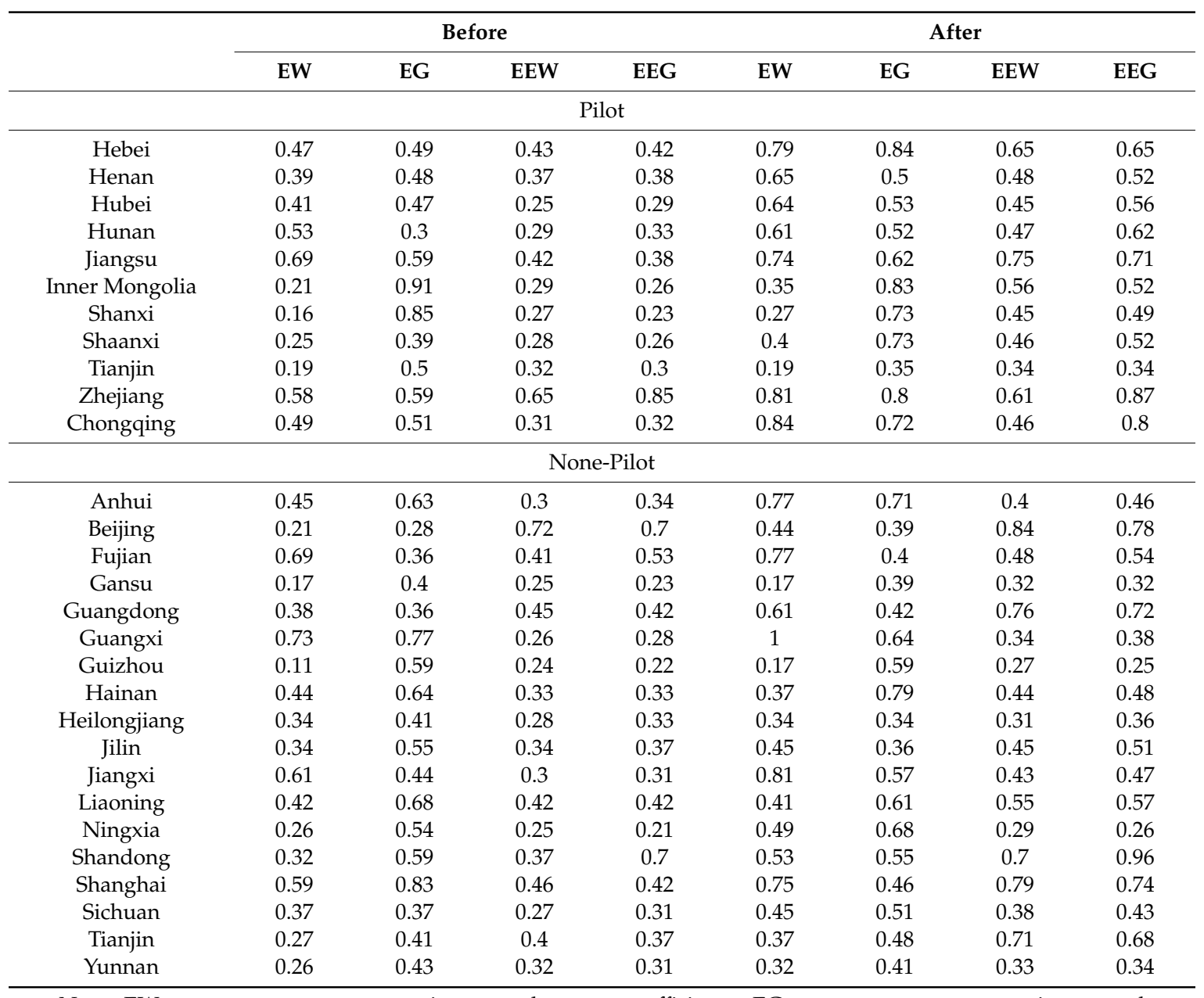

Note: EW represents wastewater environmental treatment efficiency; EG represents waste gas environmental treatment efficiency; EEW represents wastewater environmental economic efficiency; EEG represents.

It can be seen from Table 2 that the environmental treatment efficiencies in the pilot period are generally higher than in the non-pilot period and the EG is higher than EW. The treatment efficiencies in the developed regions are higher than those in the developing regions. Guangxi is the only province that has achieved effective environmental treatment for wastewater. Anhui, Fujian, Hebei, Jiangsu, Jiangxi, Shanghai, Zhejiang, and Chongqing have higher wastewater treatment efficiency than the national average, which is over 0.75 after the pilot, while the EW in eastern areas such as Gansu, Guizhou, and Xinjiang is much lower at less than 0.2. The treatment efficiency for air pollution in the pilot areas such as Hainan, Hebei, Inner Mongolia, Shanxi, Shaanxi, Zhejiang, and Chongqing is at a high level. Hebei Province has the highest with 0.84 after treatment, followed by Inner Mongolia, Zhejiang, and Shanxi. 
The changes in EEW and EEG are similar to those of EW and EG. The average value of environmental efficiency improved significantly after pilot implementation. Beijing, Guangdong, Jiangsu, Shandong, Shanghai, and Tianjin have relatively high EEWs, with the highest value of 0.84 in Beijing, and the largest growth in Shandong Province (an increase of 0.4), while the EEWs in the under-developed regions like Guizhou Province and Ningxia are much lower than the national average, at 0.27 and 0.29, respectively. The EEGs in Beijing, Shanghai, and Guangdong regions are the highest in the country. Shandong, Jiangsu, Zhejiang, and Chongqing also achieved higher EEG performances, for example, Shandong with 0.96, and Jiangsu and Chongqing with 0.71 and 0.8 , respectively, after the pilot.

An important finding is that the changes in EG/EW are not consistent with EEG/EEW, meaning that a higher EG/EW in an area is not associated with higher levels of EEG/EEW. For example, the EG in Inner Mongolia over the 2007-2012 period ranked second highest in the country but was in the lower level in terms of EEG. This is because of the relatively lower value of industrial output or development of the economy. Although it is more efficient in environmental quality and governance, its environmental economic efficiency is lower. Thus, it is important to discuss the diversity of the regions.

\subsection{Propensity Score Matching}

Given the estimated regional environmental treatment efficiencies, we use PSM to select the control group among the remaining non-pilot provinces before the implementation of the emissions trading trials from 2003 to 2006 . The implementation method is divided into the following steps. First, the logit model is selected to estimate all the variables in Table 1 that may affect environmental efficiency (EW/EG/EEW/EEG), and then the propensity score is calculated. Second, the area closest to the treated group is selected as the control group by a matching of the propensity score values. Before performing PSM, we perform a simple regression on the influencing factors. The matching results are shown in Tables 3 and 4. Table 3 indicated that the $t$-values for the average treatment effect on the treat (ATT) in the four models are less than 1.96, which implies there is no difference between the treated group and the control group.

Table 3. The Results of Propensity Score Matching.

\begin{tabular}{ccccccc}
\hline Variable & Sample & Treated & Controls & Difference & S.E. & t-Value \\
\hline \multirow{2}{*}{ EW } & Unmatched & 0.4 & 0.41 & -0.003 & 0.041 & -0.08 \\
& ATT & 0.4 & 0.38 & 0.023 & 0.041 & 0.56 \\
EEW & Unmatched & 0.4 & 0.41 & -0.003 & 0.041 & -0.08 \\
& ATT & 0.4 & 0.38 & 0.023 & 0.041 & 0.56 \\
EG & Unmatched & 0.54 & 0.53 & 0.004 & 0.039 & 0.11 \\
& ATT & 0.54 & 0.26 & 0.177 & 0.565 & 0.31 \\
& Unmatched & 0.37 & 0.39 & -0.021 & 0.033 & -0.63 \\
& ATT & 0.37 & 0.38 & -0.015 & 0.036 & -0.43 \\
\hline
\end{tabular}

Note: 1. EW represents wastewater environmental treatment efficiency; EG represents waste gas environmental treatment efficiency; EEW represents wastewater environmental economic efficiency; EEG represents. 2. ATT represents the average treatment effect on the treat.

Table 4. Validity test for Propensity score matching.

\begin{tabular}{ccccc}
\hline Variables & \multicolumn{2}{c}{ Mean } & \multicolumn{2}{c}{ t-Test } \\
\hline eaw & Treated & Control & t-value & $\mathrm{P}>|\mathrm{t}|$ \\
plf & 11.58 & 11.73 & -0.79 & 0.43 \\
ind & 10.57 & 10.6 & -0.18 & 0.86 \\
sto & 0.45 & 0.46 & -0.78 & 0.44 \\
hi & 0.48 & 0.43 & 0.97 & 0.97 \\
gdpp & 0.7 & 0.68 & 0.98 & 0.33 \\
urb & 9.53 & 9.68 & -1.53 & 0.13 \\
\hline
\end{tabular}


As shown in Table 4 the $t$ value of the average treatment effect is less than 1.96 for all the measurements of efficiency, indicating that there is no significant difference in outcomes between the treated group and the control group. Table 4 shows that the matching results are balanced for the independent variables. 11 out of 18 provinces including Anhui, Fujian, Guangdong, Heilongjiang, Jilin, Jiangxi, Liaoning, Ningxia, Shandong, Shanghai, and Sichuan were identified as the control group using in the DID analysis. Nine of none-pilot provinces are not included in the control group. This is because the treatment group is selected based on an administrative decision rather than random selection, thus, including all these regions in the control group would lead to biased results.

\subsection{Empirical Results of DID}

The pilot areas were selected based on the level of development and the decisions of the Ministry of Environmental Protection, which might lead to self-selection issues. We apply a fixed-effect regression to control for the differences in regions while controlling for the time dimension [68]. The results are shown in Table 5.

Table 5. The estimate results with the full sample.

\begin{tabular}{ccccc}
\hline Variable & EW & EEW & EG & EEG \\
\hline eaw & $0.054^{* *}$ & -0.023 & $0.09^{* * *}$ & -0.006 \\
& $(2.69)$ & $(-1.37)$ & $(4.11)$ & $(-0.35)$ \\
plf & 0.013 & 0.023 & 0.008 & 0.034 \\
& $(0.44)$ & $(0.95)$ & $(0.25)$ & $(1.34)$ \\
ind & -0.366 & $-0.481^{*}$ & $-0.878^{* *}$ & -0.165 \\
& $(-1.2)$ & $(-1.98)$ & $(-2.84)$ & $(-0.63)$ \\
sto & -0.201 & -0.124 & -0.08 & -0.134 \\
& $(-1.52)$ & $(-1.13)$ & $(-0.58)$ & $(-1.15)$ \\
hi & -0.402 & $-0.395^{*}$ & -0.016 & -0.301 \\
& $(-1.97)$ & $(-2.35)$ & $(-0.08)$ & $(-1.68)$ \\
gdpp & $0.235^{* * *}$ & $0.301^{* * *}$ & $0.249^{* * *}$ & $0.327 * * *$ \\
& $(5.97)$ & $(9.29)$ & $(6.05)$ & $(9.45)$ \\
urb & $-0.312^{* * *}$ & 0.027 & $-0.392^{* * *}$ & 0.075 \\
& $(-2.07)$ & $(0.28)$ & $(-2.64)$ & $(0.76)$ \\
period*treated & 0.063 & $0.081^{* *}$ & $0.079^{* *}$ & $0.139 * * *$ \\
year & $(1.72)$ & $(2.68)$ & $(2.66)$ & $(4.30)$ \\
Fixed-effect & yes & yes & yes & yes \\
& yes & yes & yes & yes \\
_cons & $-3.761^{* * *}$ & $-2.049^{* *}$ & $-4.732^{* * *}$ & $-2.899 * * *$ \\
N & $(-4.29)$ & $(-2.84)$ & $(-5.16)$ & $(-3.76)$ \\
& 220 & 220 & 220 & 220 \\
\hline
\end{tabular}

Note: 1 . EW represents wastewater environmental treatment efficiency; EG represents waste gas environmental treatment efficiency; EEW represents wastewater environmental economic efficiency; EEG represents. 2. In parentheses is the T Statistics; $3 .{ }^{*} p<0.05,{ }^{* *} p<0.01,{ }^{* * *} p<0.001$.

The coefficient of the interaction term between the pilot period and the pilot region (period ${ }^{*}$ treated) is used to evaluate the policy effect. As can be seen from Table 6, the coefficient of interaction is positive, which indicates that the impact of the emissions trading policy on environmental efficiency is positive. The effects of the policy for $E G$ and $E E G$ are statistically significant at a level of $0.1 \%$, and the effects of the policy for EEW are statistically significant at a level of $5 \%$, while the effects of the policy are weak on $E W$. 
Table 6. The estimate results with the subsample.

\begin{tabular}{|c|c|c|c|c|c|c|c|c|}
\hline \multirow[b]{2}{*}{ Variable } & \multicolumn{4}{|c|}{ Eastern Region } & \multicolumn{4}{|c|}{ Central and Western Region } \\
\hline & EW & EEW & EG & EEG & EW & EEW & EG & EEG \\
\hline eaw & $\begin{array}{c}0.085^{* * *} \\
(3.86)\end{array}$ & $\begin{array}{l}-0.008 \\
(-0.61)\end{array}$ & $\begin{array}{c}0.077^{* *} \\
(2.91)\end{array}$ & $\begin{array}{l}-0.016 \\
(-0.79)\end{array}$ & $\begin{array}{l}0.015 \\
(0.31)\end{array}$ & $\begin{array}{l}-0.003 \\
(-0.07)\end{array}$ & $\begin{array}{c}0.129 * * \\
(3.12)\end{array}$ & $\begin{array}{l}-0.020 \\
(-0.51)\end{array}$ \\
\hline plf & $\begin{array}{l}0.044 \\
(1.31)\end{array}$ & $\begin{array}{l}0.015 \\
(0.78)\end{array}$ & $\begin{array}{l}0.062 \\
(1.54)\end{array}$ & $\begin{array}{l}-0.037 \\
(-1.23)\end{array}$ & $\begin{array}{c}0.0034 \\
(0.05)\end{array}$ & $\begin{array}{l}0.026 \\
(0.46)\end{array}$ & $\begin{array}{l}0.001 \\
(0.01)\end{array}$ & $\begin{array}{l}0.039 \\
(0.72)\end{array}$ \\
\hline ind & $\begin{array}{l}-0.550 \\
(-1.82)\end{array}$ & $\begin{array}{l}-0.013 \\
(-0.08)\end{array}$ & $\begin{array}{l}-0.741^{*} \\
(-2.04)\end{array}$ & $\begin{array}{l}-0.549^{*} \\
(-2.01)\end{array}$ & $\begin{array}{l}-0.830 \\
(-0.86)\end{array}$ & $\begin{array}{l}-1.892 * \\
(-2.38)\end{array}$ & $\begin{array}{l}-1.124 \\
(-1.37)\end{array}$ & $\begin{array}{l}-1.243 \\
(-1.65)\end{array}$ \\
\hline sto & $\begin{array}{l}-0.157 \\
(-1.19)\end{array}$ & $\begin{array}{l}-0.071 \\
(-0.95)\end{array}$ & $\begin{array}{l}-0.114 \\
(-0.72)\end{array}$ & $\begin{array}{c}-0.0960 \\
(-0.81)\end{array}$ & $\begin{array}{l}-0.376 \\
(-0.57)\end{array}$ & $\begin{array}{l}-0.324 \\
(-0.59)\end{array}$ & $\begin{array}{l}-1.101 \\
(-1.96)\end{array}$ & $\begin{array}{l}-0.299 \\
(-0.58)\end{array}$ \\
\hline$h i$ & $\begin{array}{l}-0.422 \\
(-1.81)\end{array}$ & $\begin{array}{l}-0.130 \\
(-0.97)\end{array}$ & $\begin{array}{l}-0.095 \\
(-0.34)\end{array}$ & $\begin{array}{l}-0.051 \\
(-0.24)\end{array}$ & $\begin{array}{l}-0.003 \\
(-0.01)\end{array}$ & $\begin{array}{c}-1.720^{* * * *} \\
(-4.23)\end{array}$ & $\begin{array}{l}-0.201 \\
(-0.48)\end{array}$ & $\begin{array}{c}-1.196^{* *} \\
(-3.09)\end{array}$ \\
\hline$g d p p$ & $\begin{array}{c}0.155^{* * *} \\
(3.46)\end{array}$ & $\begin{array}{c}0.211^{* * *} \\
(8.23)\end{array}$ & $\begin{array}{c}0.279 * * * \\
(5.18)\end{array}$ & $\begin{array}{c}0.259 * * * \\
(6.41)\end{array}$ & $\begin{array}{c}0.315^{* *} \\
(2.78)\end{array}$ & $\begin{array}{c}0.496^{* * *} \\
(5.34)\end{array}$ & $\begin{array}{c}0.277^{* *} \\
(2.89)\end{array}$ & $\begin{array}{c}0.430 * * * \\
(4.89)\end{array}$ \\
\hline urb & $\begin{array}{l}-0.001 \\
(-0.01)\end{array}$ & $\begin{array}{c}0.147^{*} \\
(1.93)\end{array}$ & $\begin{array}{c}-0.487^{* *} \\
(-2.17)\end{array}$ & $\begin{array}{l}0.021 \\
(0.56)\end{array}$ & $\begin{array}{l}-0.214^{*} \\
(-1.97)\end{array}$ & $\begin{array}{l}0.201 \\
(1.04)\end{array}$ & $\begin{array}{l}-0.157 \\
(-1.41)\end{array}$ & $\begin{array}{l}0.211 \\
(1.61)\end{array}$ \\
\hline $\begin{array}{l}\text { Period }^{*} \\
\text { treated }\end{array}$ & $\begin{array}{l}0.070 \\
(1.81)\end{array}$ & $\begin{array}{l}0.087^{*} \\
(1.98)\end{array}$ & $\begin{array}{l}0.186^{*} \\
(2.50)\end{array}$ & $\begin{array}{c}0.157^{* * *} \\
(4.51)\end{array}$ & $\begin{array}{l}-5.104 * \\
(-2.54)\end{array}$ & $\begin{array}{l}-4.273 * \\
(-2.60)\end{array}$ & $\begin{array}{l}-2.688 \\
(-1.58)\end{array}$ & $\begin{array}{c}-4.820 * * \\
(-3.09)\end{array}$ \\
\hline _cons & $\begin{array}{l}-1.232 \\
(-1.00)\end{array}$ & $\begin{array}{l}-0.223 \\
(-0.32)\end{array}$ & $\begin{array}{c}-4.944^{* *} \\
(-3.34)\end{array}$ & $\begin{array}{l}-1.866 \\
(-1.68)\end{array}$ & $\begin{array}{l}0.095 \\
(1.08)\end{array}$ & $\begin{array}{l}0.061 \\
(0.84)\end{array}$ & $\begin{array}{l}0.044 \\
(0.95)\end{array}$ & $\begin{array}{l}0.088 \\
(1.28)\end{array}$ \\
\hline$N$ & 130 & 130 & 130 & 130 & 90 & 90 & 90 & 90 \\
\hline
\end{tabular}

Note: 1. EW represents wastewater environmental treatment efficiency; EG represents waste gas environmental treatment efficiency; EEW represents wastewater environmental economic efficiency; EEG represents. 2. Eastern region includes Jiangsu, Tianjin, Zhejiang provinces; Central and western regions include Hebei, Henan, Hunan, Hubei, Inner Mongolia, Shanxi, Shaanxi, Chongqing provinces 3. In parentheses is the T Statistics; $4 .{ }^{*} p<0.05$, ** $p<0.01,{ }^{* * *} p<0.001$.

The improvement of per capita GDP ( $g d p p)$ can significantly improve regional environmental governance and environmental economic efficiencies. With the improvement of the economy, people's demand for high-quality environmental quality also rises. This forces the transformation of the industrial structure and leads the heavily polluting enterprises to invest in advanced technology for environmental protection. Enterprises actively pursue profits while taking into account the total emission controls.

An increase in the urbanization $(u r b)$ significantly reduces environmental governance efficiency but improves environmental economic efficiency. The acceleration of the urbanization process may lead to some negative effects on environmental governance, but this does not mean that the size of the city should be reduced $[58,60]$. As long as the economic benefits brought by an increase in the urbanization can offset the costs that its environment can bear, the city can continue to steadily grow.

The coefficients of enterprise self-financing investment on the environment (ewa) are significantly positive for $E W$ and $E G$, implying that the increase in corporate environmental protection awareness is associated with greater capital investment and higher environmental governance efficiency. However, the coefficients of corporate self-funded variables for $E E W$ and $E E G$ are insignificant. An intuitive explanation is that investments in environmental protection, such as purchasing environmental protection equipment, reduce profits. As Villegas and Coria (2010) mentioned, the emissions trading policy in China is mainly completed under the governance framework and the price is transferred or sold to the government at a fixed ratio, which leads to the underestimation of the value of emission rights [69]. The cost of using emission rights to pollute is much lower than self-governance. Moreover, the framework of China's emissions trading platform has not been completed, and its distribution is relatively unfair in some areas. Enterprises that need to produce a certain amount of emissions have to reduce their profits due to the higher fees for paid emission rights. 
The effect of industrial proportion on environmental efficiency (ind), in general, is negative, consistent with our expectations, implying that a higher proportion of industry reduces the level of environmental efficiency. However, this is only statistically significant for EEW and EG. Reducing the degree of industrialization can improve the quality of the water environment, achieving a win-win situation for the economy and emissions reduction, but it has little effect on the governance of the atmospheric environment.

The coefficients of heavy industry (hi) are negative and only statistically significant at the $5 \%$ level for EEW. The cost of treatment of heavy polluting enterprises such as the chemical industry and metal smelting is higher and worsens environmental degradation. Reducing the proportion of heavy industry can improve environmental efficiency by decreasing the consumption of energy and lead to economic dividends through resource utilization and technological progress [54]. However, the economic output brought by an increase in the heavy industry cannot make up for the social costs resulting from their environmental externalities [65].

The degree of regional environmental supervision $(p l f)$ shows an insignificant impact on efficiency in all four equations. This may be due to the incomplete legislative and regulatory systems in China's emissions trading policy. Similarly, the proportion of state-owned and state-holding enterprises (sto) has negative coefficients on environmental efficiency, but these are insignificant. State-owned and state-controlled industrial enterprises with low environmental supervision could increase their profitability by ignoring the impact of their pollutants on the environment. In contrast, non-state-owned enterprises can improve the efficiency of environmental governance with lower costs.

\subsection{Results in Subsample and Robustness Test}

The significant imbalance in social development in the eastern and western regions may lead to heterogeneity. This study divides the sample into the central and western regions and the eastern region to compare results between the regions (Table 6).

Table 6 shows that the emissions trading policies in the eastern region can significantly improve the economic efficiency of the wastewater environment (EEW) and the environmental and economic efficiency of air pollution governance (EG and EEW), while the emissions trading policies in central and western regions can significantly improve the environmental and economic efficiency of the wastewater environment (EG and EEW) and the economic efficiency of air pollution governance (EEW). But the marginal effects are much larger in central and western regions. This might be because of the relatively high level of economic and social development in the eastern region, for which other approaches to environmental pollution control, such as environmental tax pilots and water resource compensation, may be better suited. The effect of the emissions trading policy is insignificant in those regions. Moreover, most of the polluting industries have been moved out of the eastern region and replaced by the service sector. There is a greater demand for emission rights in the central and western regions, in which the trade policy is easier to implement. This suggests that policy implementation needs to pay more attention to the central and western regions, especially in terms of environmental and economic efficiency.

In order to test the robustness results, we add a lag term of the implementation of the emission trading policy for study periods. The results in Table 7 consist of the previous analysis and suggest that the emissions trading policy has a significant impact on the economic efficiency of the water environment, and the environmental and economic efficiency of the atmospheric environment. 
Table 7. The robustness test for the DID.

\begin{tabular}{ccccc}
\hline Variable & EW & EEW & EG & EEG \\
\hline \multirow{2}{*}{ period } & -0.002 & $-0.082^{*}$ & -0.048 & -0.071 \\
& $(-0.03)$ & $(-2.08)$ & $(-0.94)$ & $(-1.67)$ \\
period treated & 0.051 & $0.076^{*}$ & $0.083^{*}$ & $0.131^{* * *}$ \\
eaw & $(1.33)$ & $(2.37)$ & $(1.99)$ & $(3.80)$ \\
& $0.050^{*}$ & -0.034 & $0.090^{* * *}$ & -0.02 \\
plf & $(2.45)$ & $(-1.96)$ & $(4.04)$ & $(-1.07)$ \\
& 0.007 & 0.032 & 0.003 & 0.051 \\
ind & $(0.23)$ & $(1.23)$ & $(0.10)$ & $(1.82)$ \\
& -0.381 & -0.471 & $-0.976^{* *}$ & -0.229 \\
sto & $(-1.22)$ & $(-1.80)$ & $(-2.87)$ & $(-0.81)$ \\
& -0.133 & -0.152 & -0.036 & -0.136 \\
hi & $(-0.94)$ & $(-1.29)$ & $(-0.23)$ & $(-1.07)$ \\
& -0.387 & -0.096 & -0.012 & -0.017 \\
gdpp & $(-1.72)$ & $(-0.51)$ & $(-0.05)$ & $(-0.08)$ \\
& $0.231^{* * *}$ & $0.315^{* * *}$ & $0.222^{* * *}$ & $0.337 * * *$ \\
urb & $(6.10)$ & $(9.94)$ & $(5.41)$ & $(9.84)$ \\
& $-0.197^{* *}$ & 0.084 & $-0.227^{* * *}$ & 0.187 \\
cons & $(-2.84)$ & $(1.24)$ & $(-4.94)$ & $(1.57)$ \\
N & $-3.843^{* * *}$ & $-2.574^{* * *}$ & $-4.665^{* * *}$ & $-3.373^{* * *}$ \\
& $(-4.28)$ & $(-3.42)$ & $(-4.78)$ & $(-4.15)$ \\
& 198 & 198 & 198 & 198 \\
\hline
\end{tabular}

Note: 1. EW represents wastewater environmental treatment efficiency; EG represents waste gas environmental treatment efficiency; EEW represents wastewater environmental economic efficiency; EEG represents. 2. In parentheses is the T Statistics; $3 .{ }^{*} p<0.05,{ }^{* *} p<0.01,{ }^{* * *} p<0.001$.

\section{Conclusions and Policy Implementation}

This study assessed the evolution of China's emissions trading system in the pilot areas and applied a DEA-SBM method to measure regional efficiency indicators: environmental governance efficiency and environmental economic efficiency. A DID method was used to evaluate the implementation effects of the emissions trading system. The results indicate that the emissions trading policy has significantly improved environmental efficiency in the pilot provinces. However, the effects are heterogeneous with different efficiency measures across different regions. Higher impacts on environmental economic efficiency were found in the central and western regions.

Increasing investment in environmental protection funds can significantly improve environmental efficiency. The self-financing of environmental protection funds by enterprises may lead to a decline in economic efficiency due to its cost, but the results suggested that the negative impact is weak. The government should encourage enterprises to increase investment in environmental protection funds and build environmental protection projects by offering loans with lower interest rates and promoting the sustainable development of environmental resources to achieve a win-win situation for economic development and environmental improvement.

The emissions trading policy in China has shown an effective impact on governance efficiency for air pollution, but the impact on the efficiency of wastewater management is still weak. The main reason is that, although water pollution is a problem in multiple administrative areas leading, the body responsible for the pollution is not clear [34]. In practice, most of the basins are across multi-provinces, while different provinces have different trading systems and regulations. This will lead to serious issues in the policy implementation, such as administrative and trade barriers over the regions and high transaction costs (information collection cost and negotiation costs). The basin authority should take the lead in setting up a trading market and platform for water pollution rights. This will mean that water pollution rights can be traded freely and effectively in markets over the whole basin. This could help reducing transaction costs, and administrative and trade barriers, as well as encouraging enterprises to participate $[70,71]$. 
The emissions trading system has significantly improved environmental efficiencies in the central and western regions, indicating that the promotion of emission selling policies in the central and western regions can effectively improve environmental quality. For this reason, more environmental management efforts should focus on the central and western regions through, for example, pollution and emission supervision and punishment, encouraging industrial enterprises to participate, improving the system of sewage charges, and making diverse emissions trading policies to achieve environmental emission reduction tasks and objectives.

Author Contributions: Conceptualization: Y.Z., S.L.; methodology: Y.Z., S.L.; validation: S.L., Y.Z., F.Z.; formal analysis: S.L., Y.Z.; investigation: Y.Z.; resources: Y.Z.; data Curation: S.L., Y.Z.; writing original draft and preparation: Y.Z., S.L.; Writing—Review and Editing: Y.Z., S.L., F.Z.; visualization: S.L., Y.Z.; supervision: Y.Z.; project administration: Y.Z.; funding acquisition: Y.Z. All authors have read and agreed to the published version of the manuscript.

Funding: This research was funded by National Social Science Foundation of China, grant number No. 17BJY215 and Global Development and Environment Fund of Zhejiang University of Technology.

Acknowledgments: This study was supported by National Social Science Foundation of China (No. 17BJY215) and Global Development and Environment Fund of Zhejiang University of Technology.

Conflicts of Interest: The authors declare no conflict of interest.

\section{Appendix A}

Table A1. Results of Unit root test for all variables.

\begin{tabular}{ccc}
\hline Variables & Statistics $(\bar{t})$ & H0: Contain Unit Roots \\
\hline$E W$ & $-2.56^{* * *}$ & Reject \\
$E E W$ & $-2.49^{* * *}$ & Reject \\
$E G$ & $-5.20^{* * *}$ & Reject \\
$E E G$ & $-2.12^{* *}$ & Reject \\
eaw & $-2.49^{* * *}$ & Reject \\
$p l f$ & $-3.74^{* * *}$ & Reject \\
ind & $-3.86^{* * *}$ & Reject \\
sto & $-8.81^{* * *}$ & Reject \\
$h i$ & $-4.81^{* * *}$ & Reject \\
gdpp & $1.69^{*}$ & Reject \\
$u r b$ & $-1.6^{*}$ & Reject \\
\hline
\end{tabular}

Note: A Im-Pesaran-Shin test applied to test the Unite root for all panels. The cross-sectional averages are subtracted from the series to mitigate the impact of cross-sectional dependence. The number of lags of the series is chosen such that the AIC for the regression is minimized. ${ }^{*} p<0.05,{ }^{* *} p<0.01,{ }^{* * *} p<0.001$.

\section{References}

1. Lu, Z.N.; Chen, H.; Hao, Y.; Wang, J.; Song, X.; Mok, T.M. The dynamic relationship between environmental pollution, economic development and public health: Evidence from China. J. Clean. Prod. 2017, 10, $134-147$. [CrossRef]

2. Zhang, H.; Zhu, Z.; Fan, Y. The impact of environmental regulation on the coordinated development of environment and economy in China. Nat. Hazards 2018, 91, 473-489. [CrossRef]

3. Li, D.; Wu, N.; Tang, S.; Su, G.; Li, X.; Zhang, Y.; Wang, G.; Zhang, J.; Liu, H.; Hecker, M.; et al. Factors associated with blooms of cyanobacteria in a large shallow lake, China. Environ. Sci. Eur. 2018, 30, 27. [CrossRef] [PubMed]

4. Li, C.; Wu, K.; Wu, J. Environmental hazard in Shanghai, China: Lessons learned from Huangpu River dead pigs incident. Nat. Hazards 2017, 88, 1269-1272. [CrossRef]

5. Shi, H.; Wang, Y.; Chen, J.; Huisingh, D. Preventing smog crises in China and globally. J. Clean. Prod. 2016, 112, 1261-1271. [CrossRef] 
6. Lu, Y.; Song, S.; Wang, R.; Liu, Z.; Meng, J.; Sweetman, A.J.; Jenkins, A.; Ferrier, R.C.; Li, H.; Luo, W.; et al. Impacts of soil and water pollution on food safety and health risks in China. Environ. Int. 2015, 77, 5-15. [CrossRef]

7. Acquaye, A.; Feng, K.; Oppon, E.; Salhi, S.; Ibn-Mohammed, T.; Genovese, A.; Hubacek, K. Measuring the environmental sustainability performance of global supply chains: A multi-regional input-output analysis for carbon, sulphur oxide and water footprints. J. Environ. Manag. 2017, 187, 571-585. [CrossRef]

8. Bergstrom, J.C.; Randall, A. Resource Economics: An. Economic Approach to Natural-Resource and Environmental Policy; Edward Elgar Publishing: Cheltenham, UK, 2016.

9. Marten, G.G. Human Ecology: Basic Concepts for Sustainable Development; Routledge: Abingdon, UK, 2010.

10. Schubert, U.; Zerlauth, A. Innovative regional environmental policy-The RECLAIM-emission trading policy. Environ. Manag. Health 1999, 10, 130-143. [CrossRef]

11. Zhang, B.; Zhang, H.; Liu, B.; Bi, J. Policy interactions and underperforming emission trading markets in China. Environ. Sci. Technol. 2013, 47,7077-7084. [CrossRef]

12. Song, Y.; Liang, D.; Liu, T.; Song, X. How China's current carbon trading policy affects carbon price? An investigation of the Shanghai Emission Trading Scheme pilot. J. Clean. Prod. 2018, 181, 374-384. [CrossRef]

13. Anthoff, D.; Hahn, R. Government failure and market failure: On the inefficiency of environmental and energy policy. Oxf. Rev. Econ. Policy 2010, 26, 197-224. [CrossRef]

14. Helm, D. Government failure, rent-seeking, and capture: The design of climate change policy. Oxf. Rev. Econ. Policy 2010, 26, 182-196. [CrossRef]

15. Kemp, R. Environmental Policy and Technical Change; Edward Elgar Publishing: Cheltenham, UK, 1997.

16. Li, Y.; Shen, K. The effect of China's pollution control policy on emission reduction-An empirical analysis based on inter-provincial industrial pollution data. Manag. World 2008, 7, 7-17.

17. Jin, X.; Shen, Z. The cap-and-trade model of incremental construction land quota: An analog with the emission permits system. China Popul. Resour. Environ. 2010, 20, 86-91.

18. Yan, W.; Guo, S. Will China's Sulphur Dioxide Emissions Fair reduce the intensity of pollution emissions? Shanghai Econ. Res. 2012, 6, 76-83.

19. Paavola, J. Institutions and environmental governance: A reconceptualization. Ecol. Econ. 2007, 63, 93-103. [CrossRef]

20. Zhou, P.; Zhang, L.; Zhou, D.Q.; Xia, W.J. Modeling economic performance of interprovincial $\mathrm{CO}_{2}$ emission reduction quota trading in China. Appl. Energy 2013, 112, 1518-1528. [CrossRef]

21. Brännlund, R.; Chung, Y.; Färe, R.; Grosskopf, S. Emissions trading and profitability: The Swedish pulp and paper industry. Environ. Resour. Econ. 1998, 12, 345-356. [CrossRef]

22. Fare, M.; Ahmed, P.O. Complementary Currency Systems Questioning Social and Economic Changes. 2014. Available online: https://base.socioeco.org/docs/fare-poa-2014.pdf (accessed on 3 September 2019).

23. Shiyi, C. Energy-Save and Emission-Abate Activity with its Impact on Industrial Win-Win Development in China: 2009-2049. Econ. Res. J. 2010, 3, 129-143.

24. Vranes, E. Trade and the Environment: Fundamental Issues in International Law, WTO Law, and Legal Theory; Oxford University Press: New York, NY, USA, 2009.

25. Wit, R.C.; Boon, B.H.; Van Velzen, A.; Cames, M.; Deuber, O.; Lee, D.S. Giving Wings to Emission Trading; Inclusion of Aviation under the European Emission Trading System (ETS); CE Delft: Delf, The Netherlands, 2005.

26. Worrell, E.; Price, L. Policy scenarios for energy efficiency improvement in industry. Energy Policy 2001, 29, 1223-1241. [CrossRef]

27. Schmalensee, R.; Joskow, P.L.; Ellerman, A.D.; Montero, J.P.; Bailey, E.M. An interim evaluation of sulfur dioxide emissions trading. J. Econ. Perspect. 1998, 12, 53-68. [CrossRef]

28. Schreifels, J.J.; Fu, Y.; Wilson, E.J. Sulfur dioxide control in China: Policy evolution during the 10th and 11th Five-year Plans and lessons for the future. Energy Policy 2012, 48, 779-789. [CrossRef]

29. Babiker, M.; Reilly, J.; Viguier, L. Is international emissions trading always beneficial? Energy J. 2004, 25, 33-56. [CrossRef]

30. Wang, P.; Dai, H.; Ren, S.; Zhao, D.; Masui, T. Achieving Copenhagen target through carbon emission trading: Economic impacts assessment in Guangdong Province of China. Energy 2015, 79, 212-227. [CrossRef]

31. Chang, Y.-T.; Park, H.; Jeong, J.; Lee, J. Evaluating economic and environmental efficiency of global airlines: A SBM-DEA approach. Transp. Res. Part. D Transp. Environ. 2014, 27, 46-50. [CrossRef] 
32. Mazzanti, M.; Zoboli, R. Environmental efficiency and labour productivity: Trade-off or joint dynamics? A theoretical investigation and empirical evidence from Italy using NAMEA. Ecol. Econ. 2009, 68, 1182-1194. [CrossRef]

33. Soytas, U.; Sari, R.; Ewing, B.T. Energy consumption, income, and carbon emissions in the United States. Ecol. Econ. 2007, 62, 482-489. [CrossRef]

34. Gielen, D.; Changhong, C. The $\mathrm{CO}_{2}$ emission reduction benefits of Chinese energy policies and environmental policies: A case study for Shanghai, period 1995-2020. Ecol. Econ. 2001, 39, 257-270. [CrossRef]

35. Park, C.-W.; Kwon, K.-S.; Kim, W.-B.; Min, B.-K.; Park, S.-J.; Sung, I.-H.; Yoon, Y.S.; Lee, K.-S.; Lee, J.-H.; Seok, J. Energy consumption reduction technology in manufacturing-A selective review of policies, standards, and research. Int. J. Precis. Eng. Manuf. 2009, 10, 151-173. [CrossRef]

36. Halkos, G.E.; Tzeremes, N.G. Exploring the existence of Kuznets curve in countries' environmental efficiency using DEA window analysis. Ecol. Econ. 2009, 68, 2168-2176. [CrossRef]

37. Reinhard, S.; Lovell, C.K.; Thijssen, G.J. Environmental efficiency with multiple environmentally detrimental variables; estimated with SFA and DEA. Eur. J. Oper. Res. 2000, 121, 287-303. [CrossRef]

38. Zhou, P.; Ang, B.W.; Poh, K.-L. A survey of data envelopment analysis in energy and environmental studies. Eur. J. Oper. Res. 2008, 189, 1-18. [CrossRef]

39. Barnum, D.; Gleason, J. Technical efficiency bias caused by intra-input aggregation in data envelopment analysis. Appl. Econ. Lett. 2005, 12, 785-788. [CrossRef]

40. Banker, R.D. Maximum likelihood, consistency and data envelopment analysis: A statistical foundation. Manag. Sci. 1993, 39, 1265-1273. [CrossRef]

41. Bajec, P.; Tuljak-Suban, D. An Integrated Analytic Hierarchy Process-Slack Based Measure-Data Envelopment Analysis Model for Evaluating the Efficiency of Logistics Service Providers Considering Undesirable Performance Criteria. Sustainability 2019, 11, 2330. [CrossRef]

42. Brady, M. Indigenous Australia and alcohol policy: Meeting difference with indifference. Aust. J. Soc. Issues 2004, 39, 477. [CrossRef]

43. Stuart, E.A.; Huskamp, H.A.; Duckworth, K.; Simmons, J.; Song, Z.; Chernew, M.E.; Barry, C.L. Using propensity scores in difference-in-differences models to estimate the effects of a policy change. Health Serv. Outcomes Res. Methodol. 2014, 14, 166-182. [CrossRef]

44. Wing, C.; Simon, K.; Bello-Gomez, R.A. Designing difference in difference studies: Best practices for public health policy research. Annu. Rev. Public Health 2018, 39, 453-469. [CrossRef]

45. Adan, H.; Fuerst, F. Do energy efficiency measures really reduce household energy consumption? A difference-in-difference analysis. Energy Effic. 2016, 9, 1207-1219. [CrossRef]

46. Miteva, D.A.; Murray, B.C.; Pattanayak, S.K. Do protected areas reduce blue carbon emissions? A quasi-experimental evaluation of mangroves in Indonesia. Ecol. Econ. 2015, 119, 127-135. [CrossRef]

47. Zhang, Y.-J.; Peng, Y.-L.; Ma, C.-Q.; Shen, B. Can environmental innovation facilitate carbon emissions reduction? Evidence from China. Energy Policy 2017, 100, 18-28. [CrossRef]

48. Moutinho, V.; Madaleno, M.; Robaina, M. The economic and environmental efficiency assessment in EU cross-country: Evidence from DEA and quantile regression approach. Ecol. Indic. 2017, 78, 85-97. [CrossRef]

49. Memon, A.G.; Harijan, K.; Uqaili, M.A.; Memon, R.A. Thermo-environmental and economic analysis of simple and regenerative gas turbine cycles with regression modeling and optimization. Energy Convers. Manag. 2013, 76, 852-864. [CrossRef]

50. Fuglie, K.O.; Bosch, D.J. Economic and environmental implications of soil nitrogen testing: A switching-regression analysis. Am. J. Agric. Econ. 1995, 77, 891-900. [CrossRef]

51. Gadenne, D.L.; Kennedy, J.; McKeiver, C. An empirical study of environmental awareness and practices in SMEs. J. Bus. Ethics 2009, 84, 45-63. [CrossRef]

52. Zhicheng, C.; Porter, R. Energy management and environmental awareness in China's enterprises. Energy Policy 2000, 28, 49-63. [CrossRef]

53. Liu, S.; Persson, K.M. Situations of water reuse in China. Water Policy 2013, 15, 705-727. [CrossRef]

54. Wang, Q.; Yuan, X.; Zuo, J.; Mu, R.; Zhou, L.; Sun, M. Dynamics of Sewage Charge Policies, Environmental Protection Industry and Polluting Enterprises-A Case Study in China. Sustainability 2014, 6, 4858-4876. [CrossRef]

55. Halkos, G.E.; Tzeremes, N.G. Economic growth and environmental efficiency: Evidence from US regions. Econ. Lett. 2013, 120, 48-52. [CrossRef] 
56. Yu, Y.; Chen, D.; Zhu, B.; Hu, S. Eco-efficiency trends in China, 1978-2010: Decoupling environmental pressure from economic growth. Ecol. Indic. 2013, 24, 177-184. [CrossRef]

57. Zhang, X.-P.; Cheng, X.-M. Energy consumption, carbon emissions, and economic growth in China. Ecol. Econ. 2009, 68, 2706-2712. [CrossRef]

58. Grimmond, S.U.E. Urbanization and global environmental change: Local effects of urban warming. Geogr. J. 2007, 173, 83-88. [CrossRef]

59. Li, S.; Ma, Y. Urbanization, economic development and environmental change. Sustainability 2014, 6, 5143-5161. [CrossRef]

60. Bai, Y.; Deng, X.; Jiang, S.; Zhang, Q.; Wang, Z. Exploring the relationship between urbanization and urban eco-efficiency: Evidence from prefecture-level cities in China. J. Clean. Prod. 2018, 195, 1487-1496. [CrossRef]

61. Li, J.; Huang, X.; Kwan, M.-P.; Yang, H.; Chuai, X. The effect of urbanization on carbon dioxide emissions efficiency in the Yangtze River Delta, China. J. Clean. Prod. 2018, 188, 38-48. [CrossRef]

62. Haberl, H.; Krausmann, F. Changes in Population, Affluence, and Environmental Pressures During Industrialization: The Case of Austria 1830-1995. Popul. Environ. 2001, 23, 49-70. [CrossRef]

63. $\mathrm{Xu}, \mathrm{B}$; $\mathrm{Lin}, \mathrm{B}$. How industrialization and urbanization process impacts on $\mathrm{CO}_{2}$ emissions in China: Evidence from nonparametric additive regression models. Energy Econ. 2015, 48, 188-202. [CrossRef]

64. Zhang, B.; Bi, J.; Fan, Z.; Yuan, Z.; Ge, J. Eco-efficiency analysis of industrial system in China: A data envelopment analysis approach. Ecol. Econ. 2008, 68, 306-316. [CrossRef]

65. Xie, B.-C.; Duan, N.; Wang, Y.-S. Environmental efficiency and abatement cost of China's industrial sectors based on a three-stage data envelopment analysis. J. Clean. Prod. 2017, 153, 626-636. [CrossRef]

66. Im, K.S.; Pesaran, M.H.; Shin, Y. Testing for unit roots in heterogeneous panels. J. Econ. 2003, 115, 53-74. [CrossRef]

67. Pesaran, M.H. A simple panel unit root test in the presence of cross-section dependence. J. Appl. Econ. 2007, 22, 265-312. [CrossRef]

68. Wooldridge, J.M. Econometric Analysis of Cross Section and Panel Data; MIT Press: Cambridge, MA, USA, 2010.

69. Villegas-Palacio, C.; Coria, J. On the interaction between imperfect compliance and technology adoption: Taxes versus tradable emissions permits. J. Regul. Econ. 2010, 38, 274-291. [CrossRef]

70. Jaspers, F.G.W. Institutional arrangements for integrated river basin management. Water Policy 2003, 5, 77-90. [CrossRef]

71. Zhou, X.; Ye, W.; Zhang, B. Introducing nonpoint source transferable quotas in nitrogen trading: The effects of transaction costs and uncertainty. J. Environ. Manag. 2016, 168, 252-259. [CrossRef] [PubMed] 